\title{
Problem udzielania pomocy wojskowej podczas ,egzekucji z nieruchomości" w obradach sejmowych doby stanisławowskiej
}

Problem udzielania pomocy wojskowej w trakcie egzekucji wyroków sądowych w historiografii nie był do tej pory zbyt często poruszany. Najwięcej miejsca poświęciła mu Katarzyna Milik w artykule omawiającym postawę sądów wobec problemu egzekucji wyroków w latach $1778-1780^{1}$. Do problemu odnosił się także Maciej Trąbski w pracy dotyczącej kawalerii okresu stanisławowskiego².

W drugiej połowie XVIII w. zgodnie z oświeceniowymi tendencjami panującymi w Europie w Rzeczpospolitej pojawiły się dążenia do usprawnienia wymiaru sprawiedliwości. Przeprowadzona została reforma sądów i urzędów grodzkich. Oprócz tego wydano szereg przepisów porządkowych, na nowo zorganizowano kancelarie i uregulowano opłaty sądowe. Zreformowano także Trybunał Koronny i skrócono przebieg procesu. Ograniczona została kara śmierci. Zastępowano ją karą przymusowych robót i więzieniem. Wiązało się to z oświeceniową ideą humanitaryzacji prawa, powoli docierającą także do Rzeczpospolitej, w której władzę w 1764 r. objął zwolennik oświeceniowych reform Stanisław August ${ }^{3}$.

${ }^{1}$ K. Milik, Sady wobec problemu egzekucji wyroków w dobie rządów Rady Nieustajacej (1778-1780), ,Zeszyty Historyczne” 2014, t. XIII, s. 79-88.

${ }^{2}$ M. Trąbski, Kawaleria autoramentu narodowego armii Rzeczypospolitej Obojga Narodów w epoce stanisławowskiej. Lata 1775-1794 [w:] A. Smoliński (red.), Do szarży marsz marsz... Studia z dziejów kawalerii, t. II, Toruń 2012, s. 208, 221.

3 J. Bardach, B. Leśnodorski, M. Pietrzak, Historia ustroju i prawa polskiego, Warszawa 2001, s. 302; A. Lityński, Problem kary śmierci w Polsce 1764-1794. Z badań nad historia polskiej myśli prawniczej, „Czasopismo Prawno-Historyczne” 1988, z. 2, s. 266; idem, Myśl humanistyczna w Polsce czasu Oświecenia. Prawo karne materialne [w:] A. Lityński (red.), Z dziejów sadu i prawa, Katowice 1992. 
W prawie staropolskim istniały dwie formy egzekucji wyroków sądowych: z nieruchomości (w stosunku do posesjonatów) oraz osobista (wobec szlachty gołoty). W niniejszym tekście mowa będzie o pierwszej z nich. Dotyczyła ona spraw o długi oraz spraw spadkowych po zmarłych krewnych. Warunkiem wszczęcia postępowania egzekucyjnego były: prawomocny wyrok sądu, odmowa jego wykonania oraz nieprzedawnienie wyroku wynoszące trzy lata i trzy miesiące od chwili wydania. Jedynie złożenie apelacji mogło wstrzymać wykonanie egzekucji sądowej.

Proces egzekucji można podzielić na kilka etapów. W pierwszym starosta wyznaczał woźnego z dwoma pomocnikami do czynności „wwiązania”, inaczej zwanej „tradycją” lub ,intromisją”. Było to nic innego jak wprowadzenie nowego właściciela w posiadanie przyznanej mu własności. Pierwsza próba jej przeprowadzenia przez woźnego zazwyczaj kończyła się niepowodzeniem ze względu na opór strony przegranej. Wówczas sąd zarządzał „zakład potrójny”, czyli pod groźbą grzywny sześciokrotnej wartości pretensji głównej ponowną „tradycję”. Jeśli strona przegrana nadal stawiała opór, to sąd ogłaszał „rumację”, czyli usunięcie siłą z zajmowanej posesji, pod groźbą banicji. Do $1768 \mathrm{r}$. starosta mógł w razie oporu wezwać okoliczną szlachtę, aby wraz z nią dokonać tzw. zajazdu i za jego pomocą dokonać ponownej „tradycji”"

Stanisław August wraz z powołaną na sejmie konwokacyjnym w 1764 r. Komisją Wojskową Koronną i powołaną na sejmie koronacyjnym Komisją Wojskową Litewską rozpoczął proces reformy armii koronnej i litewskiej. Efektem ich reformatorskich działań stała się konstytucja sejmowa z 1768 r. Zgodnie z jej zapisami każdy obywatel posiadający wyrok egzekucji dóbr, a obawiając się problemów w jego wykonaniu, mógł poprosić Komisję Wojskową o przysłanie pomocy, czego ta, jak zaznaczono, „nie powinna” odmówić. Zwrócono uwagę, aby nie ważono się dokonywać egzekucji wyroku „kupą ludzi lub kozaków” ani dokonywać zajazdu dóbr. Z kolei zaatakowanie przez dotychczasowego właściciela żołnierzy pomagających w egzekwowaniu wyroku miało oznaczać uznanie go za buntownika, a w razie gdyby doszło do zabójstwa żołnierza, mógł on zostać skazany na dwanaście tygodni w wieży oraz 2000 złp grzywny do zapłaty ${ }^{5}$. Tym samym anachroniczny już wówczas zajazd jako sposób siłowej egzekucji został prawnie zakazany.

Wybuch konfederacji barskiej, a następnie rozbiór Rzeczpospolitej dokonany przez Rosję, Austrię i Prusy zahamowały proces reform, doprowadzając m.in. do rozpadu armii. „Sejm rozbiorowy”, obradujący w latach 1773-1775, zajął się poza traktatami rozbiorowymi także reformami ustrojowymi i wojskowymi. Tym samym zmiany w prawodawstwie polskim wprowadzała od 1775 r. Rada Nieustająca.

${ }_{4}^{4}$ T. Maciejewski, Historia prawa sądowego Polski. Zarys wykładu, Koszalin 1998, s. 68; J. Bardach, B. Leśnodorski, M. Pietrzak, Historia ustroju..., s. 279-280; K. Milik, Sądy wobec problemu egzekucji wyroków..., s. 83.

5 Volumina Legum, t. VII, Petersburg 1860, s. 321. 
Z racji jej powołania na „sejmie rozbiorowym” nie cieszyła się poważaniem i zaufaniem społeczeństwa. Uważano ją za narzędzie Rosji do sprawowania kontroli nad Rzeczpospolitą. Dlatego nie można było liczyć na to, że projekty zmian prawa przedkładane kolejnym sejmom będą cieszyły się powszechną akceptacją. Jak zostanie pokazane dalej, proponowane przez Stanisława Augusta i Radę Nieustającą zmiany w prawie udzielania pomocy wojskowej podczas egzekucji z nieruchomości napotykały duży opór posłów. Podsycany był on dodatkowo przez przeciwników króla na czele z hetmanem wielkim koronnym Franciszkiem Ksawerym Branickim. Umacniał on w swoich stronnikach przekonanie, że wprowadzane zmiany, takie jak ujęcie w ramy prawne udzielania pomocy wojskowej, godzą w szlachecką wolność i przywileje. Pomimo tych trudności rozpoczął się jednak proces, którego efektem była zmiana prawa na Sejmie Czteroletnim.

Jeszcze w 1775 r. uchwalono konstytucją „Egzekucya dekretów” zobowiązanie Komisji Wojskowej do udzielania pomocy wojskowej na wniosek starostw grodowych i urzędów ziemskich. Odtąd strona, która wygrała proces, otrzymywała dekret egzekucyjny, który upoważniał do otrzymania pomocy wojskowej. Mogła być ona udzielona dopiero po zakończeniu procesu, na podstawie „Dekretu Executionis”. Jak zapisano, w razie niemożności wykonania egzekucji wyroku przez urzędowy list i manifest oficjalista sądowy mógł zwrócić się z prośbą o przysłanie żołnierzy, co Komisja „bez żadnej zwłoki uczynić będzie zobowiązana”. Inną formą były „illacje”, w których o przysłanie pomocy prosili obywatele bezpośrednio zainteresowani egzekucją. Każda ,illacja” musiała być rozpatrzona, a jej realizację miała poprzedzić stosowna rezolucja wydana przez Radę Nieustającą. Na pomoc można było liczyć, jeżeli proces sądowy przebiegał prawidłowo ${ }^{7}$.

Problem pomocy wojskowej udzielanej w ramach „tradycji” powrócił pod obrady sejmu w 1776 r. Na sesji 11 września 1776 r. kasztelan przemęcki Rafał Gurowski przedstawił projekt, ,ubezpieczenia sum ziemiańskich”. Zgodnie z zapisami, aby zapobiec upadaniu fortun szlacheckich, często wyniszczonych w efekcie konfederacji barskiej i działań wojsk zaborczych, zdecydowano o skróceniu postępowań sądowych w sprawach nabycia dóbr, które należały się np. prawem dziedziczenia. Jak zaznaczono, słabsza majątkowo strona w konflikcie nie miała szans na dochodzenie swoich praw. Dlatego dekrety miały być podpisywane przez sędziów, a proces egzekucji dóbr oddany ziemstwom i grodom. Obywatel posiadający wyrok sądu mógł skorzystać z pomocy wojskowej, ,,aby wojska narodowe na pomoc do oddania stronie przekonywującej dóbr dysponowane były"s.

${ }^{6}$ Ibidem, s. 341.

7 Volumina Legum, t. VIII, Petersburg 1860 s. 341; K. Milik, Sady wobec problemu egzekucji wyroków..., s. 84.

${ }^{8}$ Dyaryusz Seymu Ordynaryinego pod związiem konfederacyi generalney oboyga narodów agitujacego się, Warszawa 1776, s. 101. 
W trakcie debaty nad pozycją hetmana wielkiego koronnego 23 września Franciszek Ksawery Branicki odniósł się do udzielania przez wojsko pomocy wojskowej. Jego zdaniem wykonując wyroki sądowe, hetman mógł się stać uciążliwy dla obywateli, nie chciał także być uznany za stronniczego ,albo czymkolwiek nie ubliżał kursu sprawiedliwości”. Jego postępowanie spowodowane było rywalizacją ze Stanisławem Augustem i stronnikami królewskimi, skutecznie z poparciem Rosji dążącymi do odebrania hetmanowi jego pozycji i prerogatyw. Dlatego budując własne stronnictwo i nie chcąc zrażać do siebie posłów, odwoływał się on do wydanego 29 kwietnia 1775 r. ordynansu, w którym na Komisję Wojskową przerzucił obowiązek udzielania pomocy wojskowej ${ }^{9}$.

Problem pomocy wojskowej w debacie sejmowej w $1776 \mathrm{r}$. już się nie pojawiał. Natomiast zgodnie z przyjętą konstytucją „Powinności i władza Departamentów w Radzie przy boku naszym Nieustającej” w paragrafie 4 zapisano, że przy Departamencie Wojskowym (który zastąpił zlikwidowaną Komisję Wojskową) pozostawała moc wysyłania żołnierzy do egzekwowania wyroków sądowych. Od tej pory nowo powołany Departament Wojskowy Rady Nieustającej, podobnie jak wcześniej Komisja Wojskowa, nie mógł odmówić wysłania komendy ${ }^{10}$.

Kwestia egzekucji wyroków sądowych epizodycznie powróciła na sejmie w 1778 r. Poseł brzeski litewski ks. Kazimierz Nestor Sapieha na sesji 26 października zwracał uwagę, aby do pomocy wojskowej nie używać komputowego żołnierza ${ }^{11}$. Temat nie został wówczas podjęty przez posłów. Nie był to odosobniony przypadek, ponieważ sejm w $1778 \mathrm{r}$. w zasadzie sprawami wojskowymi się nie zajmował. Nie rozpatrzył propozycji wzmocnienia i budowy twierdz na terenie Rzeczpospolitej, złożonej przez mjr. inż. Jana Bakałowicza, czy propozycji wzmocnienia twierdzy w Kamieńcu Podolskim, co postulował gen. Jan de Witte ${ }^{12}$. Brak kontynuacji reform podjętych na sejmie w 1776 r. spowodowany był zbliżeniem się ambasadora rosyjskiego Otto Magnusa Stackelberga do opozycji antykrólewskiej oraz jego krytyką polityki wewnętrznej Stanisława Augusta. Bez zgody Rosji niemożliwe było dalsze reformowanie państwa, u którego granic toczyła się wojna prusko-austriacka ${ }^{13}$.

Pomimo tego między kolejnymi sejmami Rada Nieustająca starała się doprecyzować prawo o pomocy wojskowej. Najpierw 7 kwietnia 1778 r. wydała uniwersał,

\footnotetext{
9 Ibidem, s. 174.

10 Volumina Legum, t. VIII, s. 533.

${ }^{11}$ Dyaryusz seymu walnego ordynaryjnego warszawskiego sześcio niedzielnego roku pańskiego MDCCLXXVIII, Warszawa 1779, s. 126-127.

12 Ł. Cholewiński, Problematyka twierdz w obradach sejmowych w latach 1773-1786 [w:] M. Trąbski (red.), Twierdze osiemnastowiecznej Europy, t. III, Częstochowa 2020 [w druku].

${ }_{13}$ W. Filipczak, Wybory Rady Nieustajacej na sejmie w 1778 roku, „Acta Universitatis Lodziensis. Folia Historica” 1999, t. 64, s. 119. Więcej na temat stosunku Rzeczpospolitej do wojny o sukcesję bawarską z lat 1778-1779 zob. J. Michalski, Polska wobec wojny o sukcesję bawarska, Wrocław 1964.
} 
zgodnie z którym Departament Wojskowy miał delegować do każdej egzekucji tylko jednego żołnierza ${ }^{14}$. Wynikało to ze skarg wojskowych na uciążliwość, jaką była pomoc w czasie „tradycji”. Pomimo tego obciążenia nałożonego na żołnierzy Rada Nieustająca 4 maja 1779 r. potwierdziła, że Departament Wojskowy miał udzielać pomocy wszystkim, którzy jej żądali ${ }^{15}$.

Problematyka „tradycji” powróciła w obradach sejmowych w 1782 r. Strona królewska w propozycjach sejmowych wniosła projekt „Dekretu Executionis”. Zgodnie z jego zapisami oficjalista po skierowaniu listu do Departamentu Wojskowego miał od niego uzyskać pomoc wojskową, a Departamentowi zakazano rozpatrywania wniosku, przez co nie mógł odmówić wysłania żołnierzy do przeprowadzenia egzekucji wyroku. Osoba, która nie dopuszczałaby do jej przeprowadzenia, miała być karana sześciotygodniowym pobytem w wieży oraz karą 1000 złp, „nie wchodząc w rozpoznanie pryncypalnej sprawy, za samo tylko niedopuszczenie tradycji, z regestru taktowego karany być powinien". Projekt zakładał wprowadzenie regestru zatytułowanego „Dodawanie pomocy wojskowej”, w którym miał być odnotowywany każdy przypadek wysłania żołnierzy na zabezpieczenie „tradycji”. Pieczę nad księgą miała sprawować Kancelaria Wojskowa Króla. Wpisy trafiające na wokandę miały być wypisane i przybite na drzwiach Departamentu Wojskowego. W sytuacji, gdyby Departament odmówił wysłania pomocy, wnioskujący mógł się udać do Rady Nieustającej, która miała obowiązek zalecenia Departamentowi wysłania żołnierzy. Po otrzymaniu ordynansu z Departamentu Wojskowego komendanci oddziału lub subalterni (młodsi oficerowie) nie mogli wstrzymywać jego wykonania ${ }^{16}$.

W projekcie zwracano uwagę, że wojskowi często byli atakowani w czasie zabezpieczania „tradycji”, dlatego jeżeli komenda byłaby siłą wyrzucona z dóbr, to Departament powtórnie miał przysłać pomoc wojskową, a za wyrugowanie żołnierzy groziła kara czterech tygodni w górnej wieży i grzywna w wysokości 500 złp. W sytuacji, gdy wyrzucani z dóbr żołnierze zostaliby ranni, atakujący miał odsiedzieć w wieży sześć tygodni i zapłacić 1000 złp, z kolei w sytuacji śmiertelnego zranienia żołnierza kara miała wynosić dwanaście tygodni wieży i 2000 złp. Środki uzyskane z grzywny miały być dzielone po połowie między egzekwującego wyrok i skarb państwa. Pomoc wojskowa miała także obejmować zabezpieczenie posiedzeń sądu, lecz zaznaczano przy tym, że ta sama komenda nie mogła jednocześnie przystąpić do wykonania wyroku - „ta pomoc wojskowa

${ }^{14}$ Zbiór rezolucyi Rady Nieustającej potrzebnych do wiadomości jurysdykcyi sądowych i obywatelów obojga narodów, Warszawa 1785, s. 198-202.

${ }^{15}$ AGAD, Tzw. Ml, 24/VII, k. 2v.

16 Warto przywołać schemat, według którego miały być robione wpisy „Urodzony N. przeciwko N. mając supersesyję od oficjalisty N. na gruncie dóbr N. uczynioną, żąda pomocy do tradycji lub dla bezpieczeństwa sądu do dóbr N.”. 
bezpieczeństwa tylko sądu zjazdowego przestrzegając nie będzie mogła być użyta zaraz do egzekucji tegoż dekretu zjazdowego" ${ }^{17}$.

W czasie obrad sejmowych w 1782 r. po raz pierwszy problem pomocy wojskowej pojawił się w trakcie prezentowania ,protokołu czynności Rady Nieustającej” 21 października. Jak wynika z jego treści, pomoc wojskowa nie zawsze była udzielana przez Departament Wojskowy. Taki los spotkał niejakiego Tyszeckiego, któremu odmówiono, argumentując, że miał on nieprawomocny wyrok ${ }^{18}$.

W powyższym protokole wykazano także przypadek, że Rada Nieustająca na wniosek Departamentu Wojskowego cofnęła zgodę udzieloną 21 grudnia 1779 r. na pomoc wojskową. Niejaki Halczyński w memoriale żalił się, że jego przeciwnik, niejaki Wisłocki, bezprawnie domagał się pomocy wojskowej. Z racji tego, że Rada Nieustająca nie była w stanie podjąć decyzji, co dalej zrobić, postanowiła zawiesić sprawę do najbliższego sejmu ${ }^{19}$.

Jak wykazano dalej w protokole, w 1781 r. Departament Wojskowy zdecydował, że udzielanie pomocy wojskowej mogło mieć miejsce tylko po dostarczeniu pisemnych wyroków sądowych. Wobec ich braku Departament zdecydował o niewysyłaniu pomocy, nawet w sytuacji, gdyby dysponował pisemną prośbą w postaci listu i manifestu ${ }^{20}$.

Warto jeszcze przypomnieć decyzje, jakie zapadły na 51. sesji Rady Nieustającej, a odnotowane w „Protokole”. Zdecydowano wówczas, że jeśli żołnierz ochraniający „tradycję", pełniąc służbę, dopuści się wykroczenia, to będzie sądzony przez sąd wojskowy. Jeśli natomiast złamałby prawo jak „obywatel cywilny”,

${ }_{17}$ Dyariusz seymu wolnego ordynaryjnego warszawskiego sześcio niedzielnego roku pańskiego MDCCLXXXII, Warszawa 1782, s. 40.

${ }^{18}$ Ibidem, s. 134.

19 Ibidem, s. 135. Takie przypadki nie były odosobnione. Kiedy w 1781 r. Rogalińscy wystąpili o wycofanie pomocy dla rodziny Zalewskich, księży Koremieniewicza i Mokrzyckiego, cofnięto udzielenie pomocy. Byli oni spadkobiercami niejakiego Zakrzewskiego. Zostali napadnięci przez „chłopów”, a więc prawdopodobnie hajdamaków. Wnioskodawca Rogaliński, posesor dóbr tetyjowskich, w których znajdowali się aresztowani buntownicy, powołując się na obawę wywołania kolejnych buntów i odnosząc się do rezolucji Rady Nieustającej z 1779 r., zakazującej wszczynania spraw mogących prowadzić do niepokojów społecznych, zaszachował Radę, która uznała, że ustanowionego przez siebie prawa ,przeinaczyć nie miała mocy”. Jedyne, co mogła zrobić, to cofnąć udzieloną pomoc wojskową. Ibidem, s. 136.

${ }^{20}$ Ibidem, s. 146. Rada Nieustająca starała się trzymać wytycznej Departamentu, jak pokazuje przykład Orańskiego. Toczył on spór sądowy z wojewodą ruskim Stanisławem Szczęsnym Potockim i po wygranym procesie domagał się przysłania pomocy wojskowej. Ponieważ szlachcic nie okazał wyroku sądowego, uznano, że pomoc wojskowa musi zostać wstrzymana. Tak samo postąpiono, kiedy marszałek wielki koronny Stanisław Lubomirski nie przedstawił wyroku sądowego. Tutaj także zdecydowano o nieudzielaniu pomocy wojskowej. Przypadki te, jak zaznaczono w ,protokole Rady”, świadczyły o ułomności prawa i potrzebie jego uporządkowania. Ibidem, s. 146-147. 
a więc poza służbą, wówczas powinien być sądzony „w tym sądzie, pod którego bezpieczeństwo sądowe zgwałci"21.

$\mathrm{Na}$ tej samej sesji sejmowej (21 października) biskup inflancki stronnik królewski Józef Kazimierz Kossakowski wypowiedział się w sprawie dawania lub odmawiania pomocy wojskowej. Jak zaznaczał, Departament Wojskowy oskarżany był o to, że wydawał błędne decyzje w powyższej sprawie. Duchowny, broniąc Departamentu, zaznaczał, że przy tak dużej liczbie wydawanych decyzji mogły zdarzyć się pomyłki, „które więcej z obojętności prawa, jak ze złej woli pochodziły". Powołał się przy tym na sprzeczne ze sobą przepisy, które z jednej strony nakazywały wydanie zgody na wysłanie komendy po otrzymaniu listu i manifestu, a z drugiej zapewniały, że proces sądowy został przeprowadzony do końca. W tej sytuacji Departament Wojskowy, „odstępując od powołania swojego”, musiał zajmować się rozpatrywaniem „legalności procesu”. Inaczej mógłby zostać wykorzystany jako element intrygi przez osobę, która nie posiadała prawomocnego wyroku, a jedynie przesłała do Departamentu list i manifest za pośrednictwem oficjalisty sądowego. Dlatego biskup, odnosząc się do projektu królewskiego, liczył, że sejmujący przyjmą go jako ,jedyne zabezpieczenie majątków i uwolnienie Departamentu Wojskowego od przykrej [...] posługi i powinności"22.

Odmienne zdanie prezentował stronnik hetmana Branickiego Kajetan Kurdwanowski poseł czerniechowski, który na tej samej sesji zarzucił Departamentowi Wojskowemu i Radzie Nieustającej łamanie prawa w kwestii wysyłania żołnierzy na zabezpieczenie „tradycji”. Jego zdaniem zgodnie z konstytucjami z 1768 i 1776 r. nie mogły one odmówić pomocy wojskowej. Do wysłania żołnierzy wystarczył według niego sam list oficjalisty sądowego. Rada Nieustająca miała natomiast przywłaszczyć sobie prawo do wydawania wyroków: „zadecydowała materią status pod jednogłośność tylko podpadającą, a i nie tylko prerogatywę, ale władzę udzielnej jurysdykcji pod sąd podgarnęła”. Zwracał się więc do króla o „zgromienie” Rady i ukrócenie praktyk niewykonywania obowiązkowego (według niego) wysyłania żołnierzy na ochronę „tradycji” ${ }^{23}$.

Na sesji 22 października 1782 r. poseł piński Ksawery Chomiński przedstawił „Doniesienie Najjaśniejszemu Panu i stanom Rzeczpospolitej na Sejmie roku 1782 przez delegowanych do egzaminu czynności Departamentu Wojskowego uczynione". Odniósł się w nim do skarg, jakie wpływały do egzaminujących na działania Departamentu w sprawie udzielania lub odmowy pomocy wojskowej.

${ }^{21}$ Ibidem, s. 135.

${ }^{22}$ Ibidem, s. 155-156.

${ }^{23}$ Ibidem, s. 171. Również poseł poznański Walenty Godzimirski na tej samej sesji oskarżył Departament Wojskowy o przekraczanie granicy prawa i wchodzenie w kompetencje sądów. Jego zdaniem bezprawnie wydawał on zgody na udzielenie pomocy wojskowej, „lecz i w sądową wdając się kognicyję, cesje, warunki i spory, stron wnoszących rostrząsając, rezolucje czyni, a na mocy tych [...] pomoc wojskową przydaje". 
Na poparcie przytoczył piętnaście skarg. W imieniu ,poszkodowanych” domagał się zadośćuczynienia ze strony sejmu. Warto dodać, że także on wskazywał, iż Departament popełniał błędy z powodu zawiłego prawa ${ }^{24}$.

Wojewoda poznański August Sułkowski na sesji 25 października, odnosząc się do projektu królewskiego, dziękował królowi za zajęcie stanowiska w kwestii prawa o udzielaniu pomocy wojskowej. Jego zdaniem planowana zmiana prawa miała odciążyć Radę Nieustającą i Departament Wojskowy od decyzji o legalności wysyłania pomocy wojskowej25.

Na sesji w dniu 28 października 1782 r. sekretarz sejmowy Pius Kiciński przedstawił dwupunktowy projekt „Uchylenie rezolucji Rady”. W punkcie pierwszym zakazano udzielania pomocy wojskowej, jeżeli wnioskujący nie przedstawił wyroku sądu - ,tych egzekucyja dekretów i nadanie mocy rozpoznawania procesu Departamentowi Wojskowemu przeciw prawu zawierającą uchylamy”. W punkcie drugim znoszono możliwość cofania przez Radę Nieustającą udzielonej zgody na pomoc wojskową ${ }^{26}$.

Projekt nie został jednak przyjęty przez posłów i nie stał się obowiązującym prawem. Podobnie pomimo głosów poparcia nie uchwalono konstytucji, której projekt znalazł się w propozycji królewskiej. Wydaje się, że jednym z powodów, dla którego przepadł królewski projekt, była sytuacja polityczna na sejmie w 1782 r. Odbyła się wówczas sprawa uwięzienia oskarżonego o chorobę umysłową biskupa

${ }^{24}$ Ibidem, s. 196-197.

${ }^{25} \mathrm{Na}$ tej samej sesji szambelan królewski Maliński złożył skargę na działania Departamentu Wojskowego. Otrzymał on w dniu 29 maja 1781 r. rezolucję Rady Nieustającej przydzielającą mu pomoc wojskową na dokonanie ,tradycji” w dobrach szlachcica Czarneckiego. Co istotne, dysponował on wyrokiem Trybunału Koronnego. Jednak interwencja strony przeciwnej spowodowała cofnięcie decyzji o wysłaniu komendy żołnierzy. Stało się to po przesłaniu memoriału, w którym Maliński wytknął Departamentowi Wojskowemu, że ten niezgodnie z rezolucją Rady Nieustającej z 1779 r. cofnął zgodę na pomoc wojskową. Szambelan pytał posłów, czy Rada Nieustająca na podstawie zażalenia jednej strony, bez rozpatrzenia stanowiska i dokumentów strony drugiej, może cofnąć pomoc wojskową. Dodawał, że według prawa nie ma ona mocy sądowniczej, by decydować o legalności wyroków, ani mocy, by je uchylać: „prawo 1776 roku jest jasnym i wyraźnym dla jurysdykcji sądowych prawidłem, a Rada sądowej mocy nie mająca w poznanie dekretów wdawać się i egzekucji onych wstrzymać nie może”. Oskarżał także Departament, iż prowadząc tego typu praktykę i cofając pomoc wojskową, przemilcza ,prywatną pomoc” dla szlachcica dokonującego „tradycji”, tym samym dopuszczając do dokonywania zabronionych przez prawo zajazdów. Jako uzasadnienie dla swoich słów przytoczył swój problem: „podobało się jednak Radzie na takowe żądanie ur. Czarneckiego z krzywdą ur. Malińskiego pomimo prawa cofnąć pomoc wojskową, chociaż ta za ordynansem Departamentu nie Malińskiemu na Czarneckiego do tradycji, lecz oficjaliście tylko do dokończenia przemocą przerwanej kondensencyi dodana była". Maliński, odwołując się od decyzji Rady Nieustającej, otrzymał odpowiedź, że ta nie może już cofnąć podjętej rezolucji i wyczerpała moc prawną w tej sprawie, i to pomimo „doskonalszego wytłumaczenia się" szlachcica. Rada odpowiedziała, że „raz zapadłej swej Rezolucji odmienić już nie ma mocy”. Poradziła mu, aby problem wniósł pod obrady sejmu. Ibidem, s. 251.

${ }^{26}$ Ibidem, s. 292. 
krakowskiego Kajetana Sołtyka. Wykorzystanie wojska i budzące prawne wątpliwości zatrzymanie duchownego pozwoliły opozycji na aktywniejsze wystąpienie. Główny atak skierowano na Radę Nieustającą, oskarżając ją o czynienie bezprawia na senatorze Rzeczpospolitej i chęć wprowadzenia absolutyzmu królewskiego. Przekazanie koadiutorii biskupstwa krakowskiego prymasowi Michałowi Poniatowskiemu spowodowało także oskarżenie monarchy o nepotyzm ${ }^{27}$. Dlatego projekt królewski regulujący kwestie wychodzenia żołnierzy na zabezpieczenie „tradycji” nie mógł uzyskać poparcia posłów w większości tworzących antykrólewską opozycję.

Strona królewska jednak nie zamierzała rezygnować z reformy prawa o udzielaniu pomocy wojskowej. W propozycjach królewskich na sejm w 1784 r. znalazło się odwołanie do wysłanego na sejmiki projektu o egzekucjach. Król proponował, aby powołać milicje grodzkie, które zastąpiłyby wojsko w wykonywaniu wyroków sądowych. Tym samym żołnierze przestaliby być angażowani w działania niezwiązane $\mathrm{z}$ ich służbą ${ }^{28}$.

Podobnie jak dwa lata wcześniej, problem udzielania pomocy wojskowej pojawił się w trakcie prezentowania „Protokołu egzaminowania Rady Nieustającej”. Jak wynika z wystąpienia chorążego Kurzenieckiego, posła pińskiego przedstawiającego na sesji 21 października 1784 r. ,relację czynności Departamentu Wojskowego", w ciągu dwóch ostatnich lat Departament wydał 1447 zgód na udzielenie pomocy wojskowej. Nadal zdarzały się przypadki cofnięcia pomocy, czego przykładem była sprawa szlachcica Berezowskiego, który nie przedstawił wyroku sądu. Zdarzały się także przypadki powtórnego wprowadzenia komendy, co np. po napisaniu memoriału wywalczyła rodzina Rutkowskich ${ }^{29}$. Tym samym można uznać, że dość często korzystano z prawa do pomocy wojskowej w celu skutecznego przeprowadzenia „tradycji”" ${ }^{30}$.

Z kolei na sesji 21 października kasztelan witebski Michał Kossakowski, wyznaczony do „egzaminowania Departamentu Wojskowego”, zwracał uwagę, że wojsko nie powinno być używane do egzekucji dekretów sądowych, ponieważ zrażało tym do siebie obywateli oraz odrywane było od służby, na co skarżyli się dowódcy wojskowi. Proponował więc, aby województwa zgodnie z propozycją

${ }^{27}$ K. Rudnicki, Biskup Kajetan Soltyk (1715-1788), Warszawa 1908, s. 205-215; A. Stroynowski, Sejmowa opozycja antykrólewska w czasach rząów Rady Nieustającej (kryteria klasyfikacji), „Acta Universitatis Lodziensis. Folia Historica” 1984, t. 18, s. 24-25.

${ }^{28}$ Dyaryusz seymu wolnego ordynaryjnego grodzieńskiego sześcio niedzielnego roku pańskiego MDCCLXXXIV, Warszawa 1785, s. 42.

${ }^{29}$ Ibidem, s. 119.

${ }^{30}$ Ibidem, s. 105, 111-112, 114, 116, 118, 123. Warto dodać, że przedstawiający protokół egzaminowania Rady Nieustającej domagał się, aby pomoc wojskowa była dodawana także na prośbę Departamentu Policji, który nie miał możliwości siłowego egzekwowania wyroków od mieszczan. Ibidem, s. 93. 
królewską zajęły się organizacją własnych „garnizonów”, które mogłyby zabezpieczać ochronę „tradycji”"31. Tym samym opowiadał się za zorganizowaniem milicji wojewódzkich.

Odrębne zdanie prezentował kasztelan ciechanowski Józef Oborski, także członek komisji do „egzaminowania Departamentu Wojskowego”. Chwaląc Departament, zaznaczał, że „obywatel za prawem szukający pomocy wojskowej, bez odwłoki dostawał ją" ${ }^{32}$. Podobne stanowisko prezentował inny członek komisji, kasztelan żarnowski Szymon Kazimierz Szydłowski³.

Deputowani do egzaminowania czynności Departamentu Wojskowego domagali się wspólnie uchwalenia surowego prawa dla osób, które napadały na żołnierzy wysyłanych na ochronę „tradycji”. Jak argumentowano, wysyłanie wojskowych zapobiegało zajazdom i po to zostało wprowadzone ${ }^{34}$.

Królewski projekt powołania milicji poparł na sesji sejmowej 23 października wojewoda ruski Stanisław Szczęsny Potocki. Chwalił on projekt ich powołania przez województwa, zaznaczając, że powinny podlegać Departamentowi Wojskowemu - „ubezpieczy ta milicja miejsca sądowe [...] do egzekucji dekretów będzie mogła być użytą. Ulepszy żołnierza krajowego, któren już więcej w żołnierskich sprawach będzie mógł być ćwiczonym"35.

Podobną opinię na tej samej sesji przedstawił wojewoda mazowiecki Antoni Małachowski. Zaznaczał jedynie, że same województwa powinny znaleźć środki na utrzymanie milicji, podając, skąd jego zdaniem mogły one pochodzić: ,życzyłbym aby superaty Skarbów Publicznych albo na Bank Krajowy, albo na handel, albo na jakikolwiek zysk, przychodów skarbowych pomnażający do lat ośmiu i więcej obrócić". W ten sposób w skarbie miało się znaleźć kilkanaście milionów złotych polskich, które proponował wydać m.in. na utrzymanie milicji nazwanych przez niego ziemiańskimi. Karność natomiast miało zapewnić podporządkowanie ich Departamentowi Wojskowemu ${ }^{36}$.

Ciekawe stanowisko wyrażał tego samego dnia marszałek wielki litewski Władysław Roch Gurowski. Krytykował on prawo do korzystania z pomocy wojskowej, ponieważ jego zdaniem wywoływało to napięcia między posesjonatami a zabezpieczającymi „tradycję” żołnierzami. Uważał, że szlachta sama stanowiąca prawo powinna je respektować, bez odwoływania się do zbrojnej pomocy. Dlatego proponował, aby wprowadzić surowe kary w postaci utraty połowy lub części majątku dla osób utrudniających wykonanie „tradycji”. W ten sposób żołnierze nie

\footnotetext{
31 Ibidem, s. 163-164.

32 Ibidem, s. 165.

33 Ibidem, s. 166.

34 Ibidem, s. 186.

35 Ibidem, s. 293.

36 Ibidem, s. 301.
} 
musieliby pełnić obowiązków, które narażały nawet ich życie, aby wykonać wyrok sądu, a potrzebni byli do ochrony granic państwa. Krytykował on także pomysł wprowadzenia regestru, ponieważ duża liczba wpisów miała utrudniać odszukanie konkretnej własności ${ }^{37}$.

W końcu, na sesji sejmowej 28 października 1784 r., odczytany został projekt o dodawaniu pomocy wojskowej, który po przegłosowaniu stał się obowiązującym prawem, a był on kopią królewskiego projektu sprzed dwóch lat. Zgodnie z konstytucją „Decreta Executionis” jeżeli oficjalista napotykał opór w wykonaniu „tradycji”, to z manifestem wydanym w sądzie grodzkim, w którym leżały dobra, i listem miał się zwrócić do Departamentu Wojskowego. Ten nie mógł odmówić udzielenia pomocy, ponieważ zakazano mu rozpatrywania wniosków. Z kolei na osobę utrudniającą wykonanie „tradycji” miały być nałożone kary: za wyrugowanie żołnierzy groziła kara czterech tygodni w górnej wieży i grzywna w wysokości $500 \mathrm{złp}$. W sytuacji, gdy wyrzucani z dóbr żołnierze zostaliby ranni, atakujący miał odsiedzieć w wieży sześć tygodni i zapłacić 1000 złp, z kolei w sytuacji śmiertelnego zranienia żołnierza kara miała wynosić dwanaście tygodni wieży i 2000 złp. Pieniądze uzyskane z grzywny miały być dzielone po połowie między egzekwującego wyrok i skarb państwa. Dla „zachowania porządku” ustanowiony został także regestr „Dodawanie pomocy wojskowej”, który miał się znaleźć w Kancelarii Wojskowej Króla. Każdy, kto zwracał się o udzielenie pomocy wojskowej w ramach „tradycji”, miał bezpłatnie otrzymywać wpis do księgi. Same wpisy miały być uzupełniane według wzoru zaproponowanego w projekcie z 1782 r. Utrzymano także odwołanie do Rady Nieustającej w razie, gdyby Departament Wojskowy odmówił wysłania żołnierzy. Komendanci i subalterni nie mogli po otrzymaniu ordynansu wstrzymywać pomocy ${ }^{38}$. Prawo miało obowiązywać zarówno w Koronie, jak i w Wielkim Księstwie Litewskim, co zaznaczono w osobnej konstytucji „Warunek dla Wielkiego Księstwa Litewskiego"39.

W propozycjach królewskich na sejm w 1786 r. ponownie znalazł się pomysł powołania milicji. Głosu poparcia propozycji udzielił 26 października 1786 r. marszałek wielki koronny Michał Wandalin Mniszech, ,przez co i nowo ustanowione straże starościńskie zastępować by mogły żołnierza Rzeczpospolitej w egzekucji dekretów za ordynansami Wojskowego Departamentu”40. Propozycję królewską poparł również poseł wołyński podstarosta grodzki łucki Leon Hulewicz, zaznaczając, że środki na ich utrzymanie powinny być obmyślane na sejmikach gospodarskich ${ }^{41}$.

37 Ibidem, s. 113-114.

38 Volumina Legum, t. IX, Kraków 1889, s. 15-17.

39 Ibidem, s. 19.

40 Zbiór mów, głosów, przymówień, manifestów, remanifestów mianych na seymie roku 1786 , t. II, Warszawa 1787, s. 570.

41 Ibidem, s. 673. 
Z powodu uchwalenia dwa lata wcześniej konstytucji problem ten nie znalazł miejsca podczas obrad sejmowych. Nadal jednak zdarzały się przypadki nieprzyznawania pomocy wojskowej, na co skarżył się poseł inflancki Adam Felkerzamb. Kiedy kasztelan witebski Kossakowski zwrócił się do Departamentu Wojskowego o przysłanie żołnierzy na ochronę „,tradycji”, Departament odesłał sprawę do Rady Nieustającej, lecz ta nie wydała żadnej decyzji ${ }^{42}$. Również w „zarzutach przeciwko rezolucjom Rady Nieustającej” znalazły się dwa przypadki odmówienia pomocy wojskowej i jeden przypadek wstrzymania pomocy ${ }^{43}$.

Po raz ostatni problem pomocy wojskowej pojawił się w czasie obrad sejmowych na Sejmie Czteroletnim. Regulacje znalazły się w prawie powołującym Komisję Wojskową, która miała zastąpić zlikwidowany Departament Wojskowy Rady Nieustającej. W 11 paragrafie postanowiono, że utrzymana w mocy pozostanie konstytucja z 1784 r. Wprowadzono jednak kilka istotnych nowelizacji. W Koronie sąd w grodzie wydający manifest w sytuacji problemów z przeprowadzeniem ,tradycji” miał zamieszczać formułę „z użyciem nawet pomocy wojskowej i nie zajmując dóbr poprzedniczo zatradowanych". Poszkodowany mógł się teraz udać nie tylko do Komisji Wojskowej, ale także do najbliżej stacjonującego generała leutnanta lub generała majora dowodzących dywizjami armii koronnej i litewskiej. Zarówno Komisja, jak i generałowie bez rozpatrywania wniosków zobowiązani zostali do udzielenia pomocy wojskowej w liczbie dwóch szeregowych i jednego podoficera. W konstytucji z 1784 r. nie określono bowiem, jak liczna miała być wysłana do pomocy komenda. Generałowie natomiast w sytuacji wstrzymywania udzielenia pomocy mieli stawać przed Komisją Wojskową oraz zapłacić karę 1000 złp na rzecz żądającego pomocy. Z powodu zlikwidowania Rady Nieustającej, w sytuacji, gdyby Komisja Wojskowa odmówiła wysłania żołnierzy, poszkodowany miał wnieść sprawę do sądu sejmowego. W sytuacji, gdyby trzyosobowa komenda nie była w stanie skutecznie zabezpieczyć „tradycji”, generałowie lub Komisja Wojskowa mogli wysłać silniejszy oddział. Zabezpieczono także generałów i Komisję zapisem w brzmieniu: ,generałowie zaś komenderujący ani Komisja Wojskowa za dodanie pomocy za okazaniem im »Dekretu Executionis« i listu oficjalisty do żadnego sądu pociągani ani odpowiadać nie powinni”. Żołnierze wysyłani na „tradycję” mieli utrzymywać się z własnego żołdu i nie wymagać żadnych „nagród”. Jedynie dla żołnierzy regimentów pieszych wnioskodawca musiał przygotować podwody ${ }^{44}$.

W Wielkim Księstwie Litewskim urzędnik pozbawiony możliwości wykonania „tradycji” miał się udać do najbliższego sztabu dywizji. Ten w ciągu dziesięciu dni miał wysłać żołnierzy w liczbie odpowiedniej do zabezpieczenia egzekucji

42 Ibidem, s. 630.

${ }^{43}$ Zbiór mów, głosów, przymówień, manifestów, remanifestów mianych na seymie roku 1786 , t. I, Warszawa 1787, s. 314-317.

${ }^{44}$ Volumina Legum, t. IX, s. 55-56. 
sądowej. Podobnie jak w Koronie, wysłani wojskowi mogli liczyć jedynie na własny żołd. Określono także postępowanie wobec komendanta, który odmówiłby pomocy, „za zwłokę czasu nadgrodą utrat nieodwłocznie wypłacić się mających ukarze". W ciągu trzech dni od daty skargi na komendanta Komisja Wojskowa miała zlecić wysłanie komendy w sile odpowiadającej potrzebom zabezpieczenia „tradycji” „pod karą odpowiedzenia z własności i nadgrodzeniem dalszych szkód i wydatków stronie przez sądy sejmowej uznać się powinnych, na osobach komisją wojskową składających" ${ }^{45}$.

Podsumowując, należy stwierdzić, że dla posłujących obywateli problem udzielania pomocy wojskowej był ważnym zagadnieniem. Chętnie zgłaszali się do Departamentu Wojskowego, prosząc o przysłanie pomocy. Jednocześnie kolejne regulacje, począwszy od 1768 r., a kończąc na 1788 r., doprowadziły do uporządkowania procesu udzielania pomocy wojskowej w ramach „,tradycji”. Zakaz zajazdów oraz wprowadzenie kar za atak na żołnierza, świadczył o oświeceniowych zmianach w prawodawstwie Rzeczpospolitej. Należy także docenić inicjatywę królewską. Stanisławowi Augustowi nie udało się co prawda przeforsować powołania milicji, jednak przygotowana przez Radę Nieustającą i Kancelarię Wojskową Króla konstytucja z 1784 r. wyczerpywała w zasadzie wszystkie postulaty składane przez monarchę w tej sprawie. Kładła jednocześnie kres wykluczającym się przepisom prawa, które zmuszały Departament Wojskowy do decydowania o słuszności wysyłania żołnierzy. Doprecyzowaniem konstytucji z 1784 r. była konstytucja z 1788 r., wpisująca się w szereg reform podjętych przez Sejm Czteroletni w ramach reformy armii koronnej i litewskiej. Należy więc stwierdzić, że sejmy z lat 1768-1788 uporządkowały problem zabezpieczenia przez wojsko wykonywania wyroków egzekucji sądowej, nie mogąc bowiem zmienić szlacheckiej mentalności, starały się zabezpieczyć obywatela posiadającego prawomocny wyrok, a wobec braku innych środków, np. proponowanej na sejmach milicji grodzkiej lub wojewódzkiej, do końca istnienia Rzeczpospolitej wojsko to było jedyną siłą mogącą w razie potrzeby zabezpieczyć wykonanie wyroku sądowego.

THE ISSUE OF PROVIDING MILITARY ASSISTANCE

IN THE COURSE OF "REAL ESTATE FORECLOSURE” AT THE SEJM SESSIONS IN THE PERIOD OF STANISŁAW II AUGUST PONIATOWSKI

\section{Abstract}

The topic of the article is the issue of military assistance provided in the course of executions of court judgments. Due to the fact that the Sejm was the legislative body of the Polish-Lithuanian Commonwealth, the paper discusses the course of parliamentary

${ }^{45}$ Ibidem, s. 56. 
debates concerning this issue during the reign of Stanisław II August Poniatowski. The article presents the enacted parliamentary constitutions, royal projects, and analyzes the deputies' speeches. Moreover, it delineates the process of changes in the Enlightenment, which resulted in bringing order to the issue of sending soldiers on the so-called "tradition."

Keyw ords: history of law, judgment, military assistance, act 